\section{Pacific Northwest} National Laboratory

Operated by Battelle for the

U.S. Department of Energy

\title{
Group X
}

\author{
S Fields
}

July 2007

Prepared for the U.S. Department of Energy under Contract DE-AC05-76RL01830

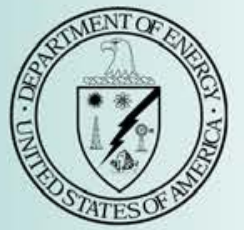




\title{
DISCLAIMER
}

This report was prepared as an account of work sponsored by an agency of the United States Government. Neither the United States Government nor any agency thereof, nor Battelle Memorial Institute, nor any of their employees, makes any warranty, express or implied, or assumes any legal liability or responsibility for the accuracy, completeness, or usefulness of any information, apparatus, product, or process disclosed, or represents that its use would not infringe privately owned rights. Reference herein to any specific commercial product, process, or service by trade name, trademark, manufacturer, or otherwise does not necessarily constitute or imply its endorsement, recommendation, or favoring by the United States Government or any agency thereof, or Battelle Memorial Institute. The views and opinions of authors expressed herein do not necessarily state or reflect those of the United States Government or any agency thereof.

\author{
PACIFIC NORTHWEST NATIONAL LABORATORY \\ operated by \\ BATTELLE \\ for the \\ UNITED STATES DEPARTMENT OF ENERGY \\ under Contract DE-AC05-76RL01830
}

Printed in the United States of America
Available to DOE and DOE contractors from the Office of Scientific and Technical Information,
P.O. Box 62, Oak Ridge, TN 37831-0062;
ph: (865) 576-8401
fax: $(865)$ 576-5728
email: reports@adonis.osti.gov

\begin{abstract}
Available to the public from the National Technical Information Service, U.S. Department of Commerce, 5285 Port Royal Rd., Springfield, VA 22161 ph: (800) 553-6847 fax: $(703) 605-6900$ email: orders@ntis.fedworld.gov online ordering: http://www.ntis.gov/ordering.htm
\end{abstract}

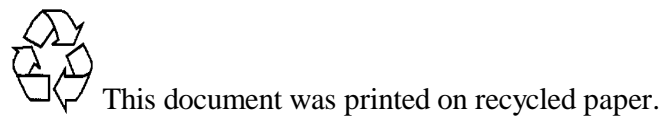




\section{Group X \\ Susannah Fields}

Disclaimer: This project is currently under contract for research through the Department of Homeland Security until 2011. The group I was responsible for studying has to remain confidential so as not to affect the current project. All dates, reference links and authors, and other distinguishing characteristics of the original group have been removed from this report. All references to the name of this group or the individual splinter groups have been changed to "Group $X$ ".

I have been collecting texts from a variety of sources intended for the use of recruiting and radicalizing members for Group X splinter groups for the purpose of researching the motivation and intent of leaders of those groups and their influence over the likelihood of group radicalization. This work included visiting many Group $\mathrm{X}$ websites to find information on splinter group leaders and finding their statements to new and old members. This proved difficult because the splinter groups of Group X are united in beliefs, but differ in public opinion. They are eager to tear each other down, prove their superiority, and yet remain anonymous. After a few weeks of intense searching, a list of eight recruiting texts and eight radicalizing texts from a variety of Group X leaders were compiled.

\section{Coding Process}

The collected texts were next input into the Qualrus software program for coding. Each document was read thoroughly and coded by unit (a full sentence) based on their themes of meaning. For example; many units referred to racial pride so White Pride became a code word I would assign to units referencing it. After seeing certain trigger words re-appear, a lexicon of possible trigger words was built for each general code. The lexicon for the code White Pride included the words equal, identity, heritage, race, White, Klan, love, and brother, among others. By the end of the coding process, six themes stood out as prominent in the documents and were assigned their own codes: White Pride, Enemy, National Government, Group X Military, Prophecy, and Action.

My coding scheme: 
White Pride: American, equal, ethnicity, heritage, identity, pride, proud, race, white pride, white, the order, peace, love, countrymen, brothers, sisters

1. Refers to Group X pride or race pride.

2. Often includes phrases that build up the group members or race members, making them feel superior in any way.

3. Includes any phrases encouraging members to be peaceful, support, or love others who may not agree with them (most harmless on the radicalization continuum - tries to make the group seem more 'caring'.) Example:

"They mean well and so we shouldn't and aren't judging any racialist group who is getting ready to start their season."

Enemy: Affirmative action, alien, black, immigrant, jew, nigger, non-whites, race, racist, segregation, spook, immigrants, subhuman, they, traitors, foreigner, them

1.References to the "other."

2. Express a dissatisfaction with other races and a desire for them to be separated.

Examples:

"Every nigger earns his livin' off the old welfare."

"The white man worries the nigger don't care."

"Niggers never bother bout goin' to work."

National Government: amendment, constitution, democracy, government, law, laws, legal, liberals, liberal, political, politicians, politician, politics, republican, republic, rights, society, united states, media, report, reporters, tv, television, news, newspaper, propaganda, story, caucus, justice, treason, country, crime, crimes

1. Includes all references to the media (generally negative).

2. Refer to all national political references. Examples:

"We have to get some people in the right places and some laws changed before it can happen." picture."

"We'll never have a third party unless Group X comes back in the

3. Often used as an excuse for action. Constitution, first and second amendments are used as a rationale for behavior.

Example:

"I have a constitutional right to do that." 
Group X Military: armor, army, battle, enemy, fight, war, require, required, requirement, blood, combat, destroy, warrior

1. Used when Group X refers to the "war" between them and the "enemy" or "other." Only refers to Group X feelings, not national government.

Examples:

"[Group X] needs you today to help fight America's battles."

"We lead the fight for freedom and for bread."

"We are now engaged in a great war."

2. Often refer to government and politics and the future of the race

Prophecy: future, prophecy, always, will

1. Prophecy as to the future state of the race or the country. This code can be hard to recognize. To cut down on confusion between this and other codes, there isn't a large lexicon because some trigger words (race, country) are not always used in a prophecy. This takes a good judgment call. Examples:

"We'll never have a third party system unless [Group X] comes back in the picture."

"We have to get some people in the right places and some laws changed before it can happen."

Action: authoritarian, duty, engaged, engage, oath, secret, secrecy, act, action, acts, choose, gave, give, learn, prepare, ready, must, will, join

1.Often seen in units with the code white pride.

2. Forceful language making a call to action by leaders. Forceful language includes wording like "You can't...!" "You must...!" "You will...!"

Examples:

"You WILL make the difference. You MUST take a stand-NOW!"

"Never surrender your firearm."

"This is a demand for you to consider the consequences if you do not take the time out to support your Brother!"

3. Includes requirements and expectations for members. Examples:

"For, those engaged in the struggle for survival of civilization...could not afford to have other than the very best - nor can we of the Fifth Era."

"The precepts of the Order are for all those who take the oath. None are exempted." 
4. Includes secrecy and phrases referring to the secrecy of members.

After a lexicon of trigger words was created Qualrus could recommend certain codes by recognizing words from the lexicon in a highlighted unit. If a successful lexicon was built, the recommended codes would usually be right.

Some words were included in a lexicon because they often are found in the coding phrases, but judgment is critical. Some lexicon words would guide the analyst to add a code that may not actually have anything to do with the whole unit. The suggestions, though often right, should be viewed as mere guidance. For example: The word learn is included in the lexicon for the code Action, but in the following sentence the code Action would not apply:

"The white American learns he is the son of rapists and enslavers, murderers and thieves, liars and hypocrites."

Though Qualrus will guide an anaylyst to code this unit as both White pride and Action, White pride is the only code that really applies.

\section{My Pattern}

While coding these texts, I realized the six general themes seemed to present a pattern of radicalization. The pattern was easily identifiable once the themes were assigned codes. The pattern is designed on a continuum following a 6-point scale ranging from harmless (recruiting) to harmful (radicalizing) language. The 6 points are (in order):

1. Constructing White identity and Aryan pride

2. Labeling the "enemy" and clarifying racial tensions

3. Addressing politics through civil rights and laws, the constitution, and American history.

4. Transitioning to powerful military language

5. Making a prophecy for the race or country

6. Implementing an authoritative call to action designed to either impede or aid the prophecy

I have found that the first two steps, the second two steps, and the third two steps can often be found grouped together in texts delivered by specific leaders; thus I break the texts down into language "thirds." Though not strictly adhered to, the general pattern I have uncovered is that the most harmless leaders (spokespeople or fervent group members) have a tendency 
to use the first third (first and second steps) in their deliveries, past Group X heads and leaders of middle important often speak of the second third (third and fourth steps), and the current Group X heads speak with the last third (or fifth and sixth steps).

To illustrate:

$1^{\text {st }}$ Third:

○ White identity and pride + racial tension and "enemy" labeling

○ Codes: White Pride, Enemy Identification

- Used by spokespeople, fervent members

$2^{\text {nd }}$ Third:

$\circ$ Politics and civil rights + military language

○ Codes: National Government, KKK Military

- Used by leaders who have stepped down, middle leaders

$3^{\text {rd }}$ Third:

○ Prophecy of race or country + authoritative call to action

- Codes: Prophecy, Action

- Used by current Group X heads

After the compilation and coding of my 16 documents, extensive research into the VICS (Verbs In Context Systems) and Framing analyzing techniques was done to determine which technique would be more useful in analyzing the texts to determine a leader's influence over their groups.

The belief behind the VICS system is that a speaker most honestly portrays themselves through their language. The VICS system, therefore, identifies verbs used in a given text and assigns the verb a rating of between -3 to +3 based on its positive or negative connotation. The verb is then measured on 17 additional points of possible language patterns and crossreferenced to determine which of the 17 points correlate. This is a very effective mode of studying a speaker's intent. Unfortunately, the texts I had collected showed that the connotation was often reversed in hate group speech. For example; the phrase "defend the truth" would have been automatically assigned a positive connotation, when, in fact, it was referencing hatful acts and was actually negative.

The second analyzing technique, framing, proved to be much more useful. Snow and Benford (2000) have researched and reported on how an 
individual's beliefs and opinions about events influence them to create personal frames. A social movement organization's leader (or entrepreneur; as referred to by Snow and Benford) is responsible for creating collective action frames (frames shared by a number of people which mobilize them for action) by manipulating events in their presentations to established and investigating members so as to shape their personal frames.

The steps I have identified in my pattern coincide with Benford \& Snow's $(1988,2000)$ decomposition of social movement organization's (SMO) core framing tasks. They break SMO's framing into three categories: diagnostic, prognostic, and motivational; all with a different purpose in an SMO's radicalization process.

\section{Diagnostic:}

According to Benford \& Snow (2000), the diagnostic framing category works as a precursor for later action by focusing blame and responsibility. Injustice frames aid this cause by identifying the victim (SMO) and how they are victimized by social injustices.

\section{Application:}

The $1^{\text {st }}$ Third category of Group X texts follows a diagnostic approach by using injustice frames to identify the White race and those of pure Aryan descent as the victims of social injustices. Step 1 of the $1^{\text {st }}$ Third specifically labels the "enemy" as anyone African American, Immigrant, Catholic, or Jewish, plus political liberals, Whites who acknowledge or help the "enemy", and most members of the media (References). Step 2 of the $1^{\text {st }}$ Third identifies the social injustices Whites are forced to endure because of the "enemy". The reported history of Group X and texts from Step 2 define some of those injustices as the corrupting of the government through affirmative action initiatives, pollution of the Aryan race, crime and fear across the country in retaliation for poor treatment, and blame of all criminal activity being placed on Whites who are only fighting back to protect their neighborhoods from such "monsters" (References).

The $1^{\text {st }}$ Third follows the diagnostic pattern by setting the stage for future actions. Steps 1 and 2 identify the victim, the enemy, and the social injustices the victim endures at the hand of the enemy. This is the most harmless end of the radicalization continuum, and meant to spur future (and more harmful) action. 


\section{Prognostic:}

The prognostic category prepares the SMO member for action by 1) proposing a plan of action, 2) giving strategies for the action, and 3) action mobilization to encourage action. This category works is in tune with the $2^{\text {nd }}$ Third of the Group X radicalization continuum.

\section{Application:}

The 3 stages of the prognostic category are enabled, in part, by counterframing (refutations of logic and rationale for actions). The $2^{\text {nd }}$ Third of the radicalization continuum uses the counterframing technique by providing rationale from civil laws. Various texts report that Klansmen feel they should not be punished for exercising their right to free speech deigned to them through the first amendment by holding public rallies in support of their beliefs. They refer to the second amendment when defending their right to bear arms and the use of those weapons for defending their property or families when "threatened" by others (Reference). One Group X head stated in an interview that the sole purpose of the existence of Group $\mathrm{X}$ was to "defend equal rights" (Reference). These examples demonstrate Group $X$ 's refutation of civil logic and their use of laws and the constitution as rationale for their behavior.

The prognostic approach also includes the movement industry, opponents, targets of influence, media, and bystanders. The Group X splinter groups address each of these groups in their recruitment and radicalization materials. In particular, Group X leaders frequently address members of the media in their interviews, blogs, letters to the public, public speeches, and recruiting propaganda. In an effort to refute logic, Group X have even admitted to publicly campaigning for the opponent of a politician they support to turn the negative media attention Group X draws in their favor (believing that if voters think Group X supports one candidate they will surely vote the other-whom Group X actually supports- to office.)

Though this is found largely in the $2^{\text {nd }}$ Third of the radicalization continuum, it should be noted that the prognostic category is incorporated into each third. Once the enemy and social injustices have been established, the prognostic approach maintains the rationale for action throughout all radicalization literature.

The prognostic theory states that the rationale for actions can differentiate one movement from another, even if they agree on the same beliefs. Group X splinter groups are good examples of this. Though all 
splinter groups relate to the original Group $\mathrm{X}$ through their beliefs on segregation, immigration, religion, and Aryan pride and principles, they disagree on the best plans of action to bring their message to the public. There is contention among the splinter groups as to whose head is more passive or more direct, the size of their group's membership, and donation techniques. Additionally, Group X is often compared to other racially-based hate groups based on their shared belief system, but these groups also choose a different rationale for and plan of action. These differences become apparent when researching the hate groups with the prognostic theory.

\section{Motivational:}

This third phase of Snow and Benford's (2000) framing process, motivational, involves a language component and a mobilization agreement. The $3^{\text {rd }}$ Third of the radicalization continuum is, not coincidentally, characterized by the use of mobilizing language and an authoritative call to action.

\section{Application:}

The difference between the final Third and the previous two is a strong, mobilizing call to action. Generally, a prophecy is made in step 5 as to the future of the race or nation if the established social justices continue, which is followed in step 6 by an authoritative urge to act. The final Third is usually delivered by the most important group heads who have the authority to make such demands. For example, when speaking to members of the one particular Group X splinter group, their head said in his public blog: "You WILL make the difference. You MUST take a stand - NOW! I don't care if you like me or [our group]. Get over it. Remember your oaths! Your loyalty is to your brother." (Reference).

Other important heads use similarly severe and urgent language characteristic of the motivational approach. They radicalize members of their splinter groups into action out of fear and a sense of duty to Group X, the White race as a whole, or their children's future. At this point in the radicalization process you see members of splinter groups organizing public rallies and marches, mobilizing behind members who have been charged with hate crimes, or rationalizing criminal behavior themselves.

\section{Wrapping Up}


Another intern on this project has done similar work. We both created our own Qualrus projects for our texts and coding patterns. The final step in the analyzing process was to write our individual coding schemes including lexicons for each code and examples for coding a unit. The intention was for us to then read each other's schemes and code a blank copy of the other's texts. We were to use the other's codes, lexicons, and directions to code documents we had never seen. By comparing the original codes from the "expert" analyzer and the codes from the "new" analyzer we would develop an idea of how applicable our patterns were depending on our ability to establish a good inter-rater agreement.

Unfortunately, saving a blank copy of a select group of important texts proved more difficult than time allowed for, and we had to result to learning each other's coding scheme and coding documents that included the original coding. We reviewed each unit and the codes assigned to it and either agreed with the coding or changed the codes based on our analysis of the same unit after reading the coding scheme. Hardly any changes were made. My opinion is that anyone would be able to code a set of documents if the original researcher had developed an excellent lexicon and easilyunderstood coding scheme. In our case the inter-rater agreement, therefore, would rely more on the original researcher's attention to detail and focus and the new researcher's competency to follow directions; less on the second researcher's abilities to actually re-analyze.

\section{Works Cited}

Benford, Robert D. \& David A. Snow. FRAMING PROCESSES 